DE DE GRUYTER

OPEN
Journal of Intercultural Management

Vol. 6, No. 4, December 2014, pp. 81-100

DOI 10.2478/joim-2014-0037

Łukasz Haromszeki*

Uniwersytet Ekonomiczny we Wrocławiu

\title{
Expected features and the behavior of talented leaders in the three sectors of the Polish economy in context with other Central-Eastern European Countries
}

\begin{abstract}
In this article the author attempts to analyze the expected features and behavior of talented leaders existing in the three sectors of the Polish economy according to presented literature the meaning of talent. The author presents confrontation between the most popular ways to explore talented individuals connected with IQ tests and a more adequate solution based on a practical approach. The in-depth diagnosis of the problems presents the basic expectations of employees towards organizational leaders in the three sectors of the Polish economy - public, private and NGO. The formulated questions in this article are appropriate for the needs of the first stage of leadership research. The conducted study shows expectations of employees from the last 23 years since the transformation of Poland and the 6 to 8 years since ISO standards were implemented in different Polish organizations and European Funds have supported Polish entrepreneurs and their personnel. In this article it also shows the results of international research about expectations of employees and future managers towards organizational leaders in different countries in Central-Eastern Europe.
\end{abstract}

Key words:talent, leadership, expectations, sectoral and cultural differences.

\section{Introduction}

If we assume that talented leaders are able to improve the quality of work in an organization and to strengthen its position in the world, it's difficult to be surprised that for many years there has been a search for leadership talent. Globalization causes the business world to create universal patterns of skills and behavior that ensure the success of the organization and its functions. This results in all organizations consciously or unconsciously, continuously or incidentally, the core of the

*lharomszeki@ue.wroc.pl 
world's dominant business culture built on a system of values and behavior characteristics of the Western world, clashes in different parts of the world with varies systems of rules specific to those local and regional cultures.

Culturally organizational behavior differs greatly, but looking at organizational leadership development programs, the best business schools in the world (in Europe, America, Asia, Australia and Africa, Financial Times Ranking of Business Schools, http://rankings.ft.com/businessschoolrankings/global-mba-rankings-2012: 16 Aug 2012), we find that they share similarities - inspired by ways of training created and carried out in the United States, Britain and France. Poland is no exception in this regard.

Looking at Poland since 2004, significant changes in management and the organizational leadership can be observed. On the one hand, Polish managers are still responsible for directing people in an autocratic style (Maczynski, Wyspianski, 2011: 7-18) and on the other hand standardized patterns of organizational behavior in the three sectors of the Polish economy. This process is the result of changes in the business-social environment. Only a few years ago there was a clear polarization: of the public, private and non-governmental sectors.

In the public sector, organizations operated with a clearly designated set of rules from the top down. During this time management (action-oriented quality of service, reduced costs) didn't matter so much but was seen to be important. Public institutions (including local governments) didn't react to the changes in the business-social environment, because the stakeholders were petitioners, and the funding was independent of the quality of management. This situation changed in the era of competition for EU funds and the implementation of ISO 9001 systems that required that the public have to be treated as clients. This resulted in improving the quality of work, reduced job security - increased qualifications and competencies requirements.

The private sector was, until recently, locally and weakly associated with worldwide business. There has been a strong process of globalization - the Polish economy and Polish companies are increasingly exposed to competition with companies from other EU countries, global corporations, and depend more on fluctuations of different currencies in the world. Success, in these conditions, can only be obtained with a serious approach to management, especially HRM - by opting for different solutions such as the creation of human capital in an organization through talent and career management.

At the beginning of the twenty-first century, the functioning of non-governmental sector was based on public subsidies, small donations and sponsoring from local businesses. Currently NGOs must and want to compete for funds from EU, national resources and grants offered by international organizations. This approach changes the functioning of the NGOs - changing their structure, employing per- 
manent staff implementing projects, not just volunteers. The observed activity and dynamism of these organizations changes the image of their management and leadership.

Different types of organizations in Poland already know that dynamic, successful survival in the changing world of the twenty-first century can provide people - especially talented leaders and has already begun to implement a variety of talent management programs. The main difficulty is, how to find a talented leader (what competences distinguish them from the business-social environment)? If finding leadership talent is almost impossible, does one, through actions directed at employees, create leaders with expected qualities, knowledge and skills? If the twenty-first century leadership requires affirmation of talent in a business-social environment, it is important to know if there are clear differences in expectations for perfect attributes and the behavior of organizational leaders in the three sectors of the Polish economy?

\section{Talent - concepts of philosophy, psychology and human resource management}

Reviewing the definitions of "talent" we have seen that most concepts of outstanding capabilities regarding them as immutable or possible to be modified with increasing experience of an individual (Listwan, 2005: 21; Armstrong, 2007: 354; Skrodzka, 2010: 27).

An example of the definition used in various scientific and professional publications is by J. S. Renzulli Model of Giftedness, which is composed of the following components (Sekowski, 2004: 35-36): above-average abilities, including general ability (high intellectual potential) and specific ability (for specific areas), creativity (originality, novelty, fluency and flexibility of thinking, solving new and unconventional problems, openness to ambiguity and uncertainty, risk-taking, sensitivity and emotional richness), commitment to work (internal discipline, perseverance in the pursuit of order, diligence, endurance, fascination with work, willingness to sacrifice and faith in their own abilities). In this approach success depends on the talent of a variety of factors, operating in areas such as personality, intelligence, emotions, motivation, temperament and creativity (Strelau, 2008).

The differentiated system of the twenty-first century organization requires leaders and other managers of certain behavior and defines dominant roles (interpersonal, information and decision-making). Their efficient performance can ensure the success of a leader and an organization. According to J. Terelak (1999: 15), the quality of work of a managerial position depends on certain abilities, such as technical efficiency (related to the preparation of theoretical and professional experience), mental agility (the condition of personality to be able to work with other people), mental acuity (the ability to diagnose, analyze any situation and make decisions). 
According to data obtained by American scientists informed decisions depend on personality traits, including: analytical skills, conceptual thinking ability and logical, intuitive ability to assess, creativity, mental strength, openness perspective, a positive self-image (Penc, 2000: 71-72). In psychology, traditional ability is divided into: general - which is global, cognitive dispositions and specific (local) - specialized in the receipt and processing of specific categories of stimuli (e.g. math, language, mechanical, graphic, manual and music skills etc.). H. Gardner (2009) describes the issue of Multiple Intelligence in detail. According to J. Terelak (1999: 71), today is dominated by view that general ability is primarily determined biologically, and special abilities are a result of interaction with the environment and based on one's own individual activities. Intelligence described in the literature included the ability to adapt to new requirements by the use of thinking, the ability to perceive relationships and draw conclusions, the ability to maintain and change the direction of target behavior, the ability to intentional, rational thinking and effective operating in near environment (Terelak: 1999:72). The leader, according to H. Gardner, must have a high ability to process different types of information, must be aware of their own abilities, preferences and prejudices and work well with a variety of stakeholders, continuously increasing capabilities of the future and create a story about a particular drama - with the construction, which refers to various components of intelligence such as existential themes, spatial setting, a logical sequence of events, musical rhythm (Gardner, 2009: 303-304).

Let us look at the practical meaning of ability (talent) mentioned, in their text, S.A. Witkowski and L. Stopyra (2010). They point out that a particularly important element of an effective manager's work is practical intelligence. The basis for the interest of various researchers concerning practical intelligence was conviction (built on the outcome) that the practical ability of humans can't be verified by IQ testing (Terelak, Baczynska, 2008). The concept of practical intelligence is derived from Sternberg's theory of intelligence, according to which intelligence is a form of development and competence, which development lets one achieve the level of an expert in a chosen field. According to U.G. Neisser (Nęcka, 2003) the measure of intelligence is the effectiveness of dealing with real life situations. Practical intelligence is the ability to acquire knowledge (informal, tacit) obtained by one's own life experiences (its level rises throughout life). Practical intelligence is also defined as the ability to search for an optimal adaptation to the requirements and challenges of the environment - adaptation, development or exploration of a new environment according to individual needs (Terelak, Baczynska, 2008).

J. Menkes (2007) based some part of his theory on analytical intelligence but also found that some part of leadership behavior did not result from analytical intelligence. J. Mankes formulated the term "executive intelligence" (in Polish translated as "leadership intelligence"), which according to him is a kind of business 
sharpness. Intelligence is a separate set of leadership skills that must show the individual in three contexts of work: the tasks, working with people and delegating duties, self-assessment and appropriate adaptation of his/her own actions. Intelligence in this approach is a set of important capabilities that drives the decision-making process and behavioral path. Leadership intelligence is rooted in critical thinking, but it is not only the capacity for abstract thinking and reasoning. It is an expanded, practical type of critical thinking and is the efficiency and effectiveness of the use of available information in thought and action. Evaluation of leadership intelligence is using realistic work scenarios. According to J. Menkes one can learn cognitive abilities that make up the leadership intelligence (for example by using the Socratic method). His studies show that there are no significant differences in IQ leadership arising from geographical origin, gender, and race (Menkes, 2007:197-199).

This understanding of intelligence revolves around understanding talent (ability), which will be the basis of the analysis of talent management issues within an organization, in this article. Talent, in the proposed approach, revealed only in the effective activity of the leader. Such an approach seems to draw on the achievements in areas of knowledge as well as pragmatism, praxeology and leadership categorization theory, social identity theory of leadership and the concept of practical intelligence.

According to pragmatism the evaluation concerns only the practical consequences of action (Tatarkiewicz, 1983). This perception of reality has strongly influenced the increase in popularity of the theory based on the analysis of various aspects of human activities from the perspective of their impact. The good, and positive were considered as an action, which ended in success. In this regard, the analysis operation is carried out from the end to the beginning of the activity. This approach allows one to explore various options for actions that can lead to success. In this way, writers describe profiles of effective leaders - because of their success, researchers and practitioners start to interested in their lives, trying to understand - why they had achieved success? Besides, if we assume that the world of business (profit-oriented organization) does not work according to perfect, absolute solutions, but is differentiated by a relative system built on optimally adapted premises action, that the essential (basic) for the study of leadership talent is praxeology. According to T. Kotarbinski - it is a goal-oriented epistemology of human behavior, which requires the organization as a condition for successful implementation (efficiency). The indicators of efficiency are: effectiveness - which is the relation between the result of the action to the state intended, and the economy - which is the relation between the result of the action to the effort incurred to achieve this (Kotarbinski, 1999). Leading people - understood to be the best possible solution, in a given place and time, the influence on subordinates (employees) is the maximization of both the above-mentioned factors. In this approach, a talented leader is 
one who understands situational conditions, makes decisions which will be a great opportunity for success.

Based on the requirements of this science created the term "praxeological competence" (Broniewska, 2010:105), which are similar to the scope of the proposed definition of the term "leadership talent". The set of competencies, created by G. Broniewska, includes: the ratio of the tasks, challenges and activities, motivation, the gift of creating a vision and engaging people in tasks, flexibility and risk taking, efficiency in managing change, stress management, time management, political skills in the form of co-operation with the environment, creating alliances and building facilities for the company.

Complementing pragmatic and socially conditioned leadership talent can be the theory of "categorized leadership", which assumes that people have their own ideas of leader optimal behavior in typical working situations or specific patterns based on cognitive types of leadership. In this perspective we can talk about the perception of leadership, because there is a process of creating prototypes, storing them in memory and run in a specific social context. "Effectively leaders are those individuals who have the attributes needed in each category of leadership, matching the requirements of a specific situation" (Kozusznik, 2005: 117). In this perspective, a talented leader can be a person who, under the requirements of the situation is highlighted by any of the 27 prototype properties for leaders (including dedication, goal-oriented, informing, charisma, responsibility, intelligence, determination, organization and verbal skills) (Lord, Foti and DeVader, 1984). According to another concept, the most important factors are: dedication, intelligence, charisma, strength and sensitivity (Offermann, J.K. Kennedy, P.W. Wirtz, 1994). The researches in the last two decades show that an effective leader must be flexible in modifying their behavior to the needs and requirements of social tasks (Hall, Workman, Marchioro, 1998; Zaccaro, Foti, Kenny, 1991). R.G. Lord also states that there is strong correlation between the perception of leadership and social power (1977). According to the described theory leadership is the result of the individual processing of information, and is not owned by specific groups (Kozusznik, 2005: 118).

According to the social identity theory of leadership (Hogg, Martin, Weeden, Epitropaki, 2001) talent of leaders can appear by bringing in the situation of dosing the impact based on individual characteristics, depending on the signal read by the leader of defining social expectations. This theory assumes that people have a tendency to divide others into categories encountered in the society that operates the terms "we" and "they" as a source of positive self-esteem due to membership in important social groups. This concept is based on the assumption that group membership affects the processes of social perception of subordinates, the appearance of a leader, his power and influence. The more the psychological importance of a groups grows, the more the processes of social identity become the basis of 
directing people (the importance of prototypicality rather than leadership characteristics) (Hogg, 2001). In the case of low-interest groups, a greater impact is built on the individual traits of leaders. According to M.A. Hogg, leader effectiveness also depends on his or her social attractiveness. It happens that with the development of the group (organization) and a longer exercise authority leaders can begin to perceive their alienation and lack of impact and defending themselves against losses in their starting position to apply more stringent measures of influence.

According to organizational leaders behavior theories we can assume that leadership talent is assigned by co-workers - that is the sum of ideas a leader should possess supported by their activities in line with expectations - perceived to be the "naturalness" of a person, and not "artificial" meaning that they are inept to adapt to the requirements of the environment.

Consequently, the present analysis, it is assumed for the purpose of this article, that talent leadership is based on the flexibility of interdisciplinary skills (competency) requirements of enrolling in a social environment.

\section{The differences in expectations towards organizational leaders existing in chosen CEE countries according to their national character}

An interesting benchmark for analyzed representatives of the three sectors of the Polish economy can be the expectations of CEE countries employees and future managers towards organizational leaders. To understand the character of each country and the typicality of the whole region of Eastern Europe, before the presentation of the results of international surveys is important to present information about "national character" as a determinant of differences in expectations existing in chosen national cultures.

\section{Cultural determinants}

Many studies of cultural differences in the social sciences use the term "national character" - having, according to some authors - a great influence on the development and organization of social life. The content of this concept is usually typical socially efficient attitudes and typical organizational skills - but always culturally, historically diverse and could be a relatively constant feature that occurs more frequently in one group than in others (Haromszeki, Jarco, 2012:194-213).

The methodological question arises in this context: whether it is legitimate to talk about "the specifics of the societies of Eastern Europe (including the region of Central Eastern Europe often perceived as people with similar characteristics)". It can be assumed, according to many different specialists in this domain, that the concept of "national character" in general can relate to the national community (Kloskowska, 1957: 10). The term "national character" and "regional CEE typicality" as some theoretical categories allow to identify and compare the ethnic com- 
munities and understand their actions. There is rich scientific literature about this question (Lewandowski, 1995: 10-11.).

This position seems to be closest to the present consideration of the genesis of a typical eastern specificities of developing countries. "Typicality" for these countries often is understand as a determined layout of social relations, organizational and entrepreneurial skills, level of social trust etc. These are patterns of behavior common for the majority, historically shaped and perpetuated through generations. This concept doesn't analyze specific features of individuals, but models of thinking, valuing and behaving sharing the majority in social and economic life.

This "typicality" is result of many different historical conditions, especially in days after the Second World War, which have had a great importance in shaping the identity of societies of the Eastern Bloc Area. Multifaceted transformation in Eastern Europe that has occurred over the last twenty years, consisted of moving from a centrally planned socialist economy to a free market economy. Lack of civil liberties, imposed consensus, lack of competitiveness or policy of full employment and low wages that characterized the preceding period, encouraged stagnation and perpetuate the passive-claim attitudes. These determinates weren't conducive for perception of civic activity as autotelic value (Haromszeki, Jarco, 2012:194-213). That state of consciousness generated later demanding attitudes and ineffective way that many people coped in the new and dynamically changing reality. Without a doubt, political changes have given many people the opportunity to demonstrate their own invention and organizational skills. Self-realization through hard work has become the social norm in many circles. The model of man absorbed and devoted to work which is common in western countries, naturally moved to the postsocialist countries. Professional and social activity has become a more important goal, than other dimensions in life.

A new period in Central Eastern Europe history, which started with many economic and social problems was a time of decreasing trust in many organizational relations. It should be added that trust in the Real Socialism Period was on a very low level, because of many different factors, for example: society was divided into two categories - power (and its fans) and opposition. It was so difficult to understand who they could believe. On the other hand there were different - closer and more informal relationships, which disappeared after 1989, when competition started in the labor market and showed unpropitious economic conditions like unemployment, inflation and sense of injustices in relationships with the owners of companies (top managers) and employees.

Trust is an essential component of leadership relations. The societies of such countries as Poland, Czech Republic, Slovakia and Romania have to "start learning" a culture of trust. 


\section{Similarities and differences}

What expectations towards organizational leaders are dominating the CEE? There are some similarities which will confirm the still existing "Eastern Block Mentality", but also new directions appropriate to modern society. There are also some differences which show the "national character" of each society as a result of existing differences of values.

The Globe Studies showed that managers from CEE for example Polish and Czech are more assertive, self-confident, with the need for power than managers from North Western Europe. They used (1996/1997) authoritarian style of management (Koopman, Maczynski,, Den Hartog, Witkowski, and 48 European coauthors, 2001: 7-22). The study of J. Maczynski (which used the same research tool as in Globe) conducted in 2010 and 2011 in Poland confirms that the authoritarian style is used more often than it was over decade ago. Many different conditions cause situations that employees prefer working relationships in which managers make decisions and take complete responsibility (J. Mączyński, D. Wyspiański, 2011:7-18).

The Korn/Ferry Institute "Emerging markets, emerging leaders. A Talent and Leadership Study of Central and Eastern Europe" (2009) shows that in CEE expectations towards organizational leaders in researching countries discover some similarities and differences.

The similarities were observed in the following expectations:

- Knowledge of the English language (and other foreign languages) and the skill of using them.

- In general, respondents felt that their countries were short of qualified talent.

- Most of respondents felt that this situation is getting better than it was ten years ago.

- 70 percent of respondents thought that leadership skills could not be learnt.

- 60 percent of respondents said that the role of the leader is significantly more important today than it was ten years ago.

- Respondents said that leaders are short-term minded and more focused on empathy than on technical intelligence, but over 60 percent of respondents said that leaders have become more focused on strategy and more involved in talent management than ten years ago.

- Over 70 percent of respondents said that their companies are not engaging their employees in formal development programs.

Scientists representing the Korn/Ferry Institute found also the differences presented below:

- Almost 70 percent of respondents in the Czech and Slovak Republics felt that their countries were short of executive talent. Less than 45 percent of respondents in Poland felt the same way. 
- Over 60 percent of the Czech and Slovak Republics respondents said that their educational institutions were failing in leadership skills learning processes. In Poland, almost 70 percent of respondents said that "their institutions were equipping their graduates with the necessary leadership skills".

- Almost 10 percent in the case of the Czech and Slovak Republics there are organizations with formal employee development programs. According to analyzing data, the situation is much better in Poland - almost 30 percent of companies have implemented formal employee development programs.

- When respondents were asked "whether talent management programs helped to improve employee satisfaction, engagement, and retention, those from the Czech and Slovak Republics were in strong agreement with the statement than those who responded from other countries".

There are also interesting outcomes of the study "Values and Leadership Expectations of Future Managers from Transforming Societies" (2011). Authors show expectations of future organizational leaders in CEE - similarities and differences.

The set of the similar characteristics consists of results presented below:

- In the Czech Republic and Romania the most important expectations towards organizational leaders is to be an effective bargainer (negotiate effectively, intelligently and always were well informed)

- In Czech, Slovakia and Romania preferred leadership dimension is team oriented leadership. Charismatic leadership was joint first in the Czech Republic and Romania.

Authors of the described study found out more differences than similarities in analyzing samples which consists of representatives of chosen societies. Those features, skills and attitudes are listed differently in the Czech Republic, Slovakia and Romania.

According to the Czech respondents the expected organizational leaders apart from bargainers should be inspirational, diplomatic and boost morale, decisive, communicative, trustworthy, interested in temporal events and act logically. They should also be dynamic which means highly involved, energetic and enthused, visionary, team integrator. (Compared with middle managers from the Czech Republic, several East European countries e. g. Hungary, Poland and Slovenia of GLOBE project in 2004, Czech Students give less emphasis on team-oriented and participative leadership behavior).

Slovaks are definitely more people oriented than other nations being a part of the research sample. According to their expectations the most effective and worthy leader to follow has these characteristics: kindness toward others, the ability to unify people, diplomacy, visionary, inspirational, and administratively competent, with personal integrity, performance oriented and decisive, should think for future and be strongly performance oriented through empowering team-work and 
team-spirit, should empower decentralization, informal relations and lose control in organizational environment, should invite their subordinates taking initiatives; sustain participation of team members in decision-making as well as pragmatic and open relationships in teams.

Romanian future managers, like Czechs, admitted that an effective leader should be, besides a bargainer, diplomatic, intelligent, communicative, administratively skilled, coordinator, inspirational, be able to motivate, trustworthy, decisive, informed, team builder and dependable.

\section{Methods}

\section{Introduction}

This is a pilot study, which will continue in the future. Prepared tool will be used to examine employees in the three sectors of the Polish economy in many different organizations (public - including local government, private - including companies after transformation from public enterprise, NGO's - large organizations with many branches and small organizations existing in local communities).

\section{Research problem}

The research problem in this study are the similarities and differences in expectations towards organizational leaders in the three sectors of the Polish economy.

Additionally studies of different expectations towards organizational leaders in several countries in CEE.

\section{General research questions}

1. What are the expectations (characteristics and behavior) of public organizations employees in Poland towards organizational leaders?

2. What are the expectations (characteristics and behavior) of private organizations employees in Poland towards organizational leaders?

3. What are the expectations (characteristics and behavior) of NGO's employees in Poland towards organizational leaders?

\section{Research methods}

The pilot study was conducted in Poland (especially in Lower Silesia). The method used was the questionnaire interview method (PAPI).

\section{Questionnaire}

The questionnaire used collected information from interviews conducted from 2006 from many different organizations: public, private and NGO's. The prior studies in this field do not have the form of a standardized research tool - they 
were more related with interviews or observation. There are also questions, which ask about some individual features (personality traits and skills) and behavior according to sets of characteristics proposed by different scientists (after their studies) from 1948.

The questionnaire contains questions which included:

- What makes a talented leader?

- In the period of your employment have you worked with someone you would call a talented leader?

- At what level of management was the manager you thought was talented?

- In your opinion do other employees have the same perception of a talented leader?

- What steps has the organization taken for the manager, who you called a gifted leader?

- If you are looking for a person ideally suited to lead an entire organization or its various departments, divisions and teams - which attributes and behavior should they poses?

Respondents had the possibility to choose one or more answers (depending on the question) from a set prepared for them which was based on previous research experiences.

\section{Sample}

In the pilot studies purposive sampling was used. The main criteria is: variety of opinions. The study was chosen from employees of various public (national and local), private (new and transformed state-owned enterprises) and non-governmental (large with many branches and small existing according to areas of expectations and needs of local communities) organizations participated in a pilot study - all of which operate in the region of Lower Silesia. A total of questioned employees 170 ( $44 \%$ from the public sector, $46 \%$ from the private sector and $10 \%$ from NGO's). The process of conducting these pilot studies allowed us to collect more information about employees expectations towards organizational leaders and the number of existing leaders in different organizations in Poland. These results will be the foundation of a tool prepared for a future study project of about 5000 employees of different organizations according the quota selection (amount of different organizations in each sector, their structure and level of employment).

In the public sector 56\% respondents were up to 35 years of age, $40 \%$ were 35 55 years of age and $4 \%$ were over $55.72 \%$ were women and $28 \%$ men. $93 \%$ had graduated from University and $7 \%$ have a high school degree. Of the private sector respondents - 33\% were under the age of 35, 56\% were between $35-55$ and $11 \%$ were over 55. 58\% were female and $42 \%$ male, $60 \%$ had graduated from university and $40 \%$ have a high school degree. NGO: $40 \%$ were up to $35,40 \%$ were between $35-55$ and $20 \%$ over $55.60 \%$ were women and $40 \%$ men. $70 \%$ had graduated from university and 30\% have a high school degree. Data was collected from July 2012. 


\section{Talented leaders - the results of pilot studies conducted in organizations from three sectors of the polish economy}

According to this study there are important differences between expectation towards organizational leaders existing in the three sectors of the Polish economy. Because of the process of modification of public organization which has had a place since 2004 (influence of EU funds expectations and ISO 9001 programs) they became closer to private organizations. Only NGOs still differ strongly from other organizations existing in the Polish economy (Figures 1,2, and 3).

Figure 1. What makes a talented leader - public sector?

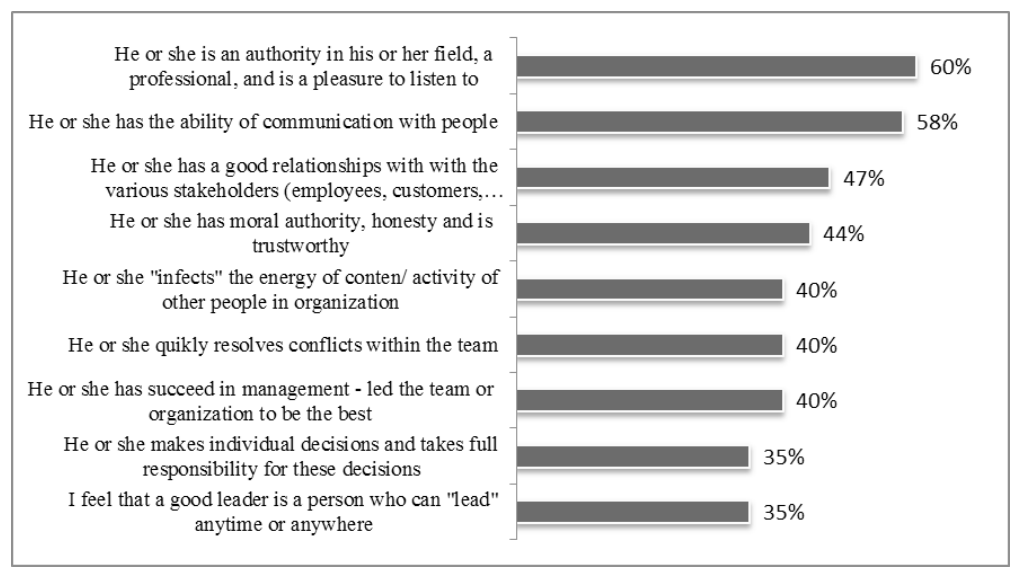

Source: own study

Figure 2. What makes a talented leader - private sector?

He or she has the ability of communication with people

He or she is an authority in his or her field, a professional, and is a pleasure to listen to

$\mathrm{He}$ or she has succeed in management - led the team or organization to be the best

$\mathrm{He}$ or she has moral authority, honesty and is trustworthy

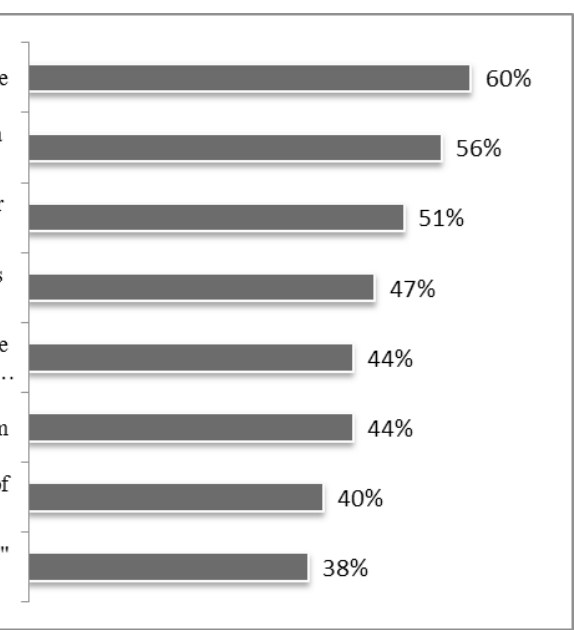

$\mathrm{He}$ or she has a good relationships with with the

various stakeholders (employees, customers,.

He or she quikly resolves conflicts within the team

$\mathrm{He}$ or she "infects" the energy of conten/ activity of other people in organization

I feel that a good leader is a person who can "lead" anytime or anywhere 
Figure 3. What makes a talented leader - NGOs?

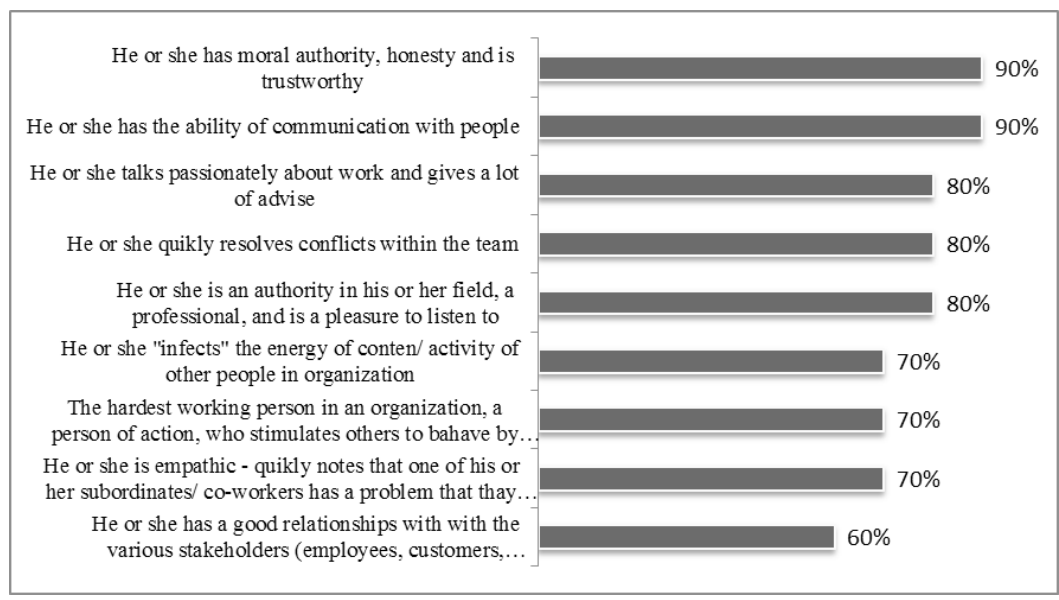

\section{Source: own study}

Respondents answered that is very difficult to meet a gifted organizational leaders, but during their professional career they have met:

- a few talented leaders (16\% answers in public, 33\% in private and $40 \% \mathrm{w}$ NGOs sector),

- only one talented leader (47\% answers in public and private organizations and $60 \%$ in NGOs),

Respondents who didn't meet any talented leaders work in public (37\%) and private $(20 \%)$ organizations.

Different character of NGOs causes people who create and coordinate activities in local communities are treated as leaders, because they find followers without using marital incentives. These results prove again that there are real differences between NGOs and public/private organizations and important changes which have had a place in last 10 years since Poland joined the EU and didn't change the character of the leadership relationship.

Most gifted leaders work as first line managers (40\% answers in public, $47 \%$ in private organizations and 60\% in NGOs). Additionally respondents met a gifted leaders on the mid-level (16\% answers in public, 38\% in private organizations and $30 \%$ in NGOs) and top-level (19\% answers in public, $22 \%$ in private organizations and $10 \%$ in NGOs).

The similarities in expectations are most visible in NGOs. $80 \%$ respondents confirm that employees of their organization agreed with them and have the same impressions about their leader. The same opinion had $68 \%$ respondents of private and $52 \%$ respondent of public organizations.

Respondents had to choose activities which were taken by the manager, who they called a gifted leader. The interviewed people decided that the most popular/ 
frequent was: provided leaders with great opportunities to make decisions (30\% answers in public, $44 \%$ in private and $50 \%$ in NGOs). Other less frequent answers:

- appreciated the leaders success / efficiency and effectiveness $(26 \%$ in public, $22 \%$ in private and $50 \%$ in NGOs),

- provided the leaders with great opportunities to develop (23\% in public, $22 \%$ in private and $30 \%$ in NGOs),

- appreciated the leaders good relationships with employees (5\% in public, $33 \%$ in private and $50 \%$ in NGOs),

- stopped him / her leaving the organization (16\% in private organization, 20\% in NGOs),

- recruited him / her (16\% in private and 10\% in NGOs),

It could be observed that a less rational approach in public organizations, in which one doesn't appreciate good relationships with employees (important part of the leadership relationship) and there weren't appropriate actions related with recruitment and retention of a gifted leaders.

There are also differences in acceptance of sets of features presented in literature since 1948. The most popular conceptions in public sector is built on research of Chełpa and Obój as follows:

- $51 \%$ - control of their own emotions and their expression, communication, team integration task forces around objectives, negotiating solutions to the needs and interests of the differences of people, the critical reception of new ideas, determination, desire for achievement / mastery, taking considered risks, responsibility, self-awareness - S. Chełpa 2002 (Listwan, 2010:165),

- $49 \%$ - self-confidence, ambition, focusing on achievement and success, assertiveness, stress tolerance, perseverance and determination, intelligence, courage, the ability to create a vision of a desired state, creativity and innovation, tact and diplomatic talents, quick decision-making, ability to organize tasks and delegating duties - K. Obłój 1997 (Kuc, 2006: 382-383).

The above presented conceptions were created by psychologists and they take into account different features related with emotional intelligence and building good relationships with employees.

The conception chosen by respondents from the private sector is more related with efficiency and efficacy in management according to the appropriate skills helpful in specific conditions. That's why in the private sector as many as $73 \%$ chose personality traits, according to the concept of J. C. Wiliams, A. J. DuBrin, H. L. Sisk 1985 (Kuc, 2006: 383-384): problem-solving skills, ability to find good jobs, professional competence, understanding people and situations, self-confidence, a high level of authority and autonomy needs, low - the need for affiliation, a sense of humor, assertiveness, sensitivity and tact, providing support, a high level of expectations to subordinates. 
Very interesting results were observed in the NGOs sector in which respondents chose two conceptions: the first - psychological - closely related with emotional intelligence, and the second - modern HRM scientist proposition - which includes qualifications and situational approach to efficient leadership. This answer could be an effect of changing market conditions (competition for UE funds) which inspired using appropriate personality traits, knowledge and skills in specific situations and the stable essence of NGOs - very emotional and related with a passionate approach. Frequent answers were (70\% respondents of NGOs) are sets of the features presented below:

- Self-confidence, ambition, focus on achievement and success, assertiveness, stress tolerance, perseverance and determination, intelligence, courage, the ability to create a vision of a desired state, creativity and innovation, tact and diplomatic talents, quick decision-making, ability to organize tasks and delegating duties K. Obłój 1997 (Kuc, 2006: 382-383).

- The ability to work with people, responsibility, the need to achieve results, the experience of leadership in the initial stages of their careers, a wide range of experience, good negotiation skills, the willingness to take risks, innovative ideas and the ability to adapt management style to any prevailing situation [Armstrong, 1999:226-227).

The study confirms some very interesting tendencies, but because this is a pilot study results cannot be generalized. There is a plan to start testing this questionnaire in a representative sample in the near future.

The expectations towards organizational leaders in the Czech Republic and Romania are more related to results of the conducted studies in the three sectors of Polish economy, than needs of future managers in Slovakia. The international research would be conducting in the three sectors of different CEE countries in the near future.

This is very important information for the HRM scientists and HR experts in Polish companies that Polish respondents of The Kern/ Ferry Institute Study are convinced that they can acquire "necessary leadership skills" in the Polish system of business education.

\section{Conclusion}

Unifying patterns of organizational behavior in different sectors of the economy affect the perception of organizational leaders. The results of perceptions of talented leaders confirm a practical dimension of social expectations in this regard. The respondents from the public sector appreciated above all the professionalism (understood as having highly developed technical skills) and interpersonal skills - especially in the field of efficient communication with various stakeholders, especially subordinates. In the private sector expectations were similar. The main difference 
is due to a much more pragmatic approach to leadership activities. In organizations which are profit-oriented, it is noted that a leader can be considered as talented, if they achieved success that had positive effects on the entire organization. Responses from NGOs, as expected, differ strongly from those given by respondents from other sectors of the economy, because in addition to communication skills, they mentioned: morality, honesty, trust and passion in the pursuit of an objective.

When the tasks of an organization are more varied and demand more commitment, the easier it is to identify a person known by the employees' as "a gifted leader ". Results show that they are mostly in non-governmental organizations, and they feature less in public institutions. In every sector of the Polish economy in the region of Lower Silesia the easiest way to find a component leader of an organization is at the lowest management level. In addition to the public sector, the respondents admits that similar views on some leaders are the same as their colleagues.

Activities in the field of human resource management, described in the earlier part of this article, rarely deviate from developed programs within an organization. It is difficult to observe employees activities supporting an outstanding manager (the leader of an organization), and encouraging them to maintain a high level of commitment to the objectives of an organization.

Most of the respondents in the three sectors of the economy admitted that the organizations strived not to disturb or upset a talented leader and appreciated their leaders success but rarely offered solutions for them requiring financial commitment or a change to the structure of an organization. The process of identifying talented leaders is mostly not connected with the real working environment - existing only as a set of impractical guidelines.

The participants in the Polish case study expected from the leader: professionalism, commitment and good relations with employees. The people selected in the survey realized that in the real world, you have to settle for much less than in the ideal world. The role of talented leaders is shaping the organizational social and business environment in order to obtain a high level of satisfaction and commitment of employees and to achieve results beyond the expectations of an organization. Maybe so, practical understanding of talent will mean that organizations will no longer be able to create abstract solutions that will support the activities of a "real" instead of "undefined" talents required to be a good leader.

A common situation to the results of the conducted study presented to the international studies in the CEE region. Respondents from Central Eastern European countries have the impression that there are not many real organizational leaders. They know exactly what set of features, knowledge and skills talented leaders should have but the real problem could result from dominative conviction that "leadership skills could not be learnt". This situation gets worse if we consider the information that organizations very rarely implement real and variable talent man- 
agement and leader development programs (some of the CEE countries have bigger problems with this issue than Poland).

Young respondents - future managers present lists of features (skills and knowledge) and styles of management which are a guarantee of success in their cultural circumstances. Whether this analysis is a description of the future organizational reality, it will depend on future managers (respondents) real attitudes and behavior. The "Western World of Business" already knows that the best solution for permanent organizational success is implementing and refreshing different development programs for example talent and succession management. Central Eastern European societies went through many changes in the last two decades. They have reduced the "competence gap" between them and the Western World and although this situation is not always visible, the amount of pragmatic people is increasing. The result of this process could be in future organizations creating their own solutions appropriate to present and plan conditions instead of keeping an ineffective alternative - copying foreign practices or not doing anything.

\section{References}

Armstrong M., (1999), Jak być lepszym menedżerem? Warszawa, Dom wydawniczy ABC.

Armstrong M., (2007), Zarzadzanie zasobami lud飞kimi, Warszawa, Wolters Kluwer Polska.

Broniewska G., (2010), Inteligencja wieloraka i jej znaczenie w rozwoju kadry kierowniczej,

T. Listwan, S. A. Witkowski (ed.), Menedżer w gospodarce opartej na wiedzy, Research Papers of Wroclaw Univeristy of Economics, 115: 214-223.

Čater T., Lang R., (2011), Values and Leadership Expectations of Future Managers from Transforming Societies, Chemnitz University of Technology, http://www.tu-chemnitz.de/wirtschaft/ bwl5/forschung/schriften/doc/16.pdf: 5.01.2013.

Emerging markets, emerging leaders. A Talent and Leadership Study of Central and Eastern Europe, (2009), The Korn/Ferry Institute, http://www.trainings.ru/f/1/pics/CEE_Talent _ Ldrshp_Study.pdf: 5.01.2013.

Extended DISC, Talent Club, www.talentclub.pl/badanie_talentu.php,16.08.2012.

Financial Times Ranking of Business Schools, http://rankings.ft.com/businessschoolrankings/ global-mba-rankings-2012: 16 Aug 2012.

Gardner H., (2009), Inteligencje wielorakie, Warszawa, MT Biznes..

Hall R. J., Workman J. W., Marchioro C. A., Sex, (1998), Task and Behaioural Flexibility Effects and Leadership Perceptions, Organizational Behavior and Human Decision Processes, Vol. 74.

Haromszeki L., Jarco P., (2012), Building a proactive attitude by using ICT among local leaders in developing countries, Proceedings of the International Conference on ICT Management for Global Competitiveness and Economic Growth in Emerging Economies (ICTM 2012):194-213.

Hogg M. A., (2001), A Social Identity Theory of Leadership, Personality and Social Psychology Review: 5. 
Hogg M. A., Martin R., Weeden K., Epitropaki O., (2001), Effective Leadership Salient Groups: Revisiting Leader-member Exchange Theory from the Perspective of the Social Identity Theory of Leadership, Queensland, University of Queensland.

Jamka B., (2010), Podmiotowe a atrybutowe zarządzanie talentami podwładnych, T. Listwan, S. A. Witkowski (ed.), Menedżer w gospodarce opartej na wiedzy, Research Papers of Wroclaw Univeristy of Economics, 115: 224-233.

Kloskowska A., (1957), Charakter narodowy a osobowość we współczesnej problematyce badań społecznych, Kultura i Społeczeństwo, vol. 1, 1: 10.

Koopman, P.L., Maczynski, J., Den Hartog, D.N., Witkowski, S.A., and 48 European co-authors, (2001), Perception of Societal Culture and Preferred Leadership Styles in North/West and South/East European Countries, Polish Journal of Applied Psychology, vol. 1, 1:7-22.

Kotarbinski T., (1999), Zasady teorii czynu, Prakseologia, vol. 1, Wrocław, Ossolineum.

Kozusznik B., (2005), Wplyw społeczny w organizacji, Warszawa, Polskie Wydawnictwo Ekonomiczne.

Kuc B. R., (2006), Od zarz̨qdzania do przywództwa, Warszawa, Wydawnictwo Menedżerskie PTM..

Lewandowski E., (1995), Charakter narodowy Polaków, Warszawa, Aneks:10-11.

Listwan T. (ed.), (2010), Zarzqdzanie kadrami, Warszawa, C. H., Beck.

ListwanT.,(2005),Zarządzanietalentami-wyzwaniewspółczesnychorganizacji,S.Borkowska (ed.), Zarzadzanie talentami, Warszawa, Instytut Pracy i Spraw Socjalnych.

Lord R. S., Foti R. J., DeVader C. L., (1984), A Test of Leadership Categorization Theory: Internal Structure, Information Processing and Leadership Perceptions, Organizational Behavior and Human Performance, Vol. 34.

Lord R.G., (1977), Functional Leadership Behavior: Measurement and Relation to Social Power and Leadership Perceptions, Administrative Science Quarterly, vol. 22.

Maczynski J., Wyspianski D., (2011), Differences on Organizational Practices and Preferred Leader Attributes Between Polish Managers Studies in 2010/2011 and 1996/1997, (ed.) L. Sulkowski, Journal of Intercultural Management, vol. 3, 2: 7-18.

Menkes J., (2007), Inteligencja przywódcza, Warszawa Studio Emka.

Offenmann L. R., Kennedy J. K., P., Wirtz W., (1994), Implicit Leadership Theories: Content, Structure and Generalizability, Leadership Quarterly, 5.

Penc J., (2000), Kreatywne kierowanie, Warszawa Placet.

Sekowski A. E., (ed), (2004), Psychologia żdolności, Wspótczesne kierunki badań, Warszawa PWN. Skrodzka A., (2010), Generalista - nowe podejście do zarządzania talentami w biznesie, (ed.) S. Lachiewicz, A. Walecka, Lodz, Monografie Politechniki Łódzkiej.

Strelau J., (2008), Psychologia, Gdansk, GWP, vol. 2.

Tatarkiewicz W., (1983), Historia filozofii, PWN, Vol. 3, Warszawa.

Terelak J. F., (1999), Psychologia menedzera, Warszawa, Difin. 
Witkowski S. A., Stopyra L., (2010)., Wiedza ukryta, inteligencja praktyczna i intuicja w pracy menedżera, T. Listwan, S. A. Witkowski (ed.), Menedżer w gospodarce opartej na wiedzy, Research Papers of Wroclaw Univeristy of Economics, 115: 812-826.

Zaccaro S. J., Foti R. J., Kenny D. A., (1991), Self-Monitoring and Trait-Based Variance in Leadership: an Investigation of Leader Flexibility Across Multiple Group Situations, Journal of Applied Psychology, vol. 76. 